m5663

84

\title{
Shaba II:
}

The French and Belgian
Intervention in Zaire in 1978

by

Lieutenant Colonel Thomas P. Odom

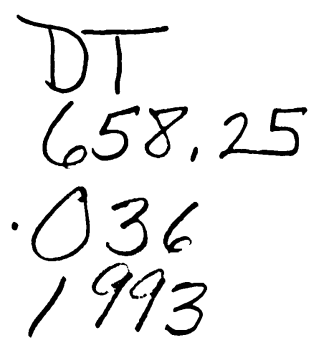

U.S. Army Command and General Staff College

Fort Leavenworth, Kansas 66027-6900

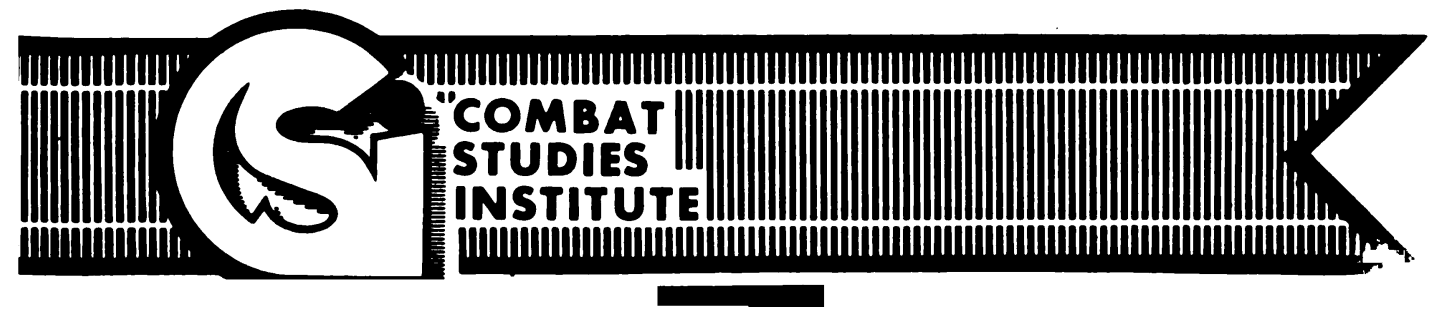

